Article

\title{
Integrated Nutrient Management Significantly Improves Pomelo (Citrus grandis) Root Growth and Nutrients Uptake under Acidic Soil of Southern China
}

\author{
Xiaoman Huang ${ }^{1,+}$, Muhammad Atif Muneer ${ }^{1,+}{ }^{\mathbb{C}}, \mathrm{Jian} \mathrm{Li}^{1}{ }^{1}$, Wei Hou ${ }^{1}$, Changcheng Ma ${ }^{1}$, Jiabin Jiao ${ }^{1}$, \\ Yuanyang Cai ${ }^{2}$, Xiaohui Chen ${ }^{1}$, Liangquan $\mathrm{Wu}^{1, *}$ and Chaoyuan Zheng ${ }^{1, *}$ \\ 1 College of Resources and Environment, International Magnesium Institute, Fujian Agriculture and Forestry \\ University, Fuzhou 350002, China; 3180831046@fafu.edu.cn (X.H.); m_atifmuneer@yahoo.com (M.A.M.); \\ 3190831053@fafu.edu.cn (J.L.); 3190831051@fafu.edu.cn (W.H.); 3190831057@fafu.edu.cn (C.M.); \\ 3190831052@fafu.edu.cn (J.J.); chenxiaohui0914@163.com (X.C.) \\ 2 College of Plant Science, Jilin University, Changchun 130062, China; caiyy19@mails.jlu.edu.cn \\ * Correspondence: liangquan01@163.com (L.W.); zhengcy@cau.edu.cn (C.Z.) \\ + These authors contributed equally to this work.
}

Citation: Huang, X.; Muneer, M.A.; Li, J.; Hou, W.; Ma, C.; Jiao, J.; Cai, Y.; Chen, X.; Wu, L.; Zheng, C. Integrated Nutrient Management Significantly Improves Pomelo (Citrus grandis) Root Growth and Nutrients Uptake under Acidic Soil of Southern China. Agronomy 2021, 11, 1231. https://doi.org/10.3390/ agronomy11061231

Academic Editors: Luca Regni, Primo Proietti and Mirko Cucina

Received: 20 May 2021

Accepted: 15 June 2021

Published: 17 June 2021

Publisher's Note: MDPI stays neutral with regard to jurisdictional claims in published maps and institutional affiliations.

Copyright: (c) 2021 by the authors. Licensee MDPI, Basel, Switzerland. This article is an open access article distributed under the terms and conditions of the Creative Commons Attribution (CC BY) license (https:// creativecommons.org/licenses/by/ $4.0 /)$.

\begin{abstract}
Root system plays a crucial role in plant growth and development by uptake of soil nutrients, which is affected by intensive use of NPK fertilizer. However, it is unknown how integrated nutrient management (INM) could affect the root growth and its nutrient uptake in the red soils of southern China. For this, the impacts of different INM practices on root morphological traits and root nutrient uptake were investigated in the pomelo tree. First, we investigated the spatial root distribution of various tree ages (i.e., 8, 13, 18, and 23 years old) and found the optimum root growth at $20-80 \mathrm{~cm}$ around the tree trunk in topsoil $(0-20 \mathrm{~cm})$. Hence, the pomelo trees were fertilized at 20-80 cm around the trunk, i.e., FFP (farmer fertilization practice), optimization NPK fertilizer $(\mathrm{O})$ combined with lime $(\mathrm{L})$ and mushroom residue $(\mathrm{M})$ known as $\mathrm{O}+\mathrm{L}+\mathrm{M}$ treatment, and $\mathrm{O}+\mathrm{L}$ combined with $\mathrm{Mg}$ fertilizer called as $\mathrm{O}+\mathrm{L}+\mathrm{Mg}$ treatment. We found that root length (RL) significantly increased by application of $\mathrm{O}+\mathrm{L}+\mathrm{M}(108.5$ and $219.1 \mathrm{~cm})$ and $\mathrm{O}+\mathrm{L}+\mathrm{Mg}(73.6,66.8 \mathrm{~cm})$ in topsoil and subsoil, respectively, in 2019. Similarly, root surface area (RSA) was significantly higher under INM, i.e., $\mathrm{O}+\mathrm{L}+\mathrm{Mg}>\mathrm{O}+\mathrm{L}+\mathrm{M}>\mathrm{FFP}$. For root diameter $(\mathrm{RD}), \mathrm{O}+\mathrm{L}+\mathrm{M}(0.8 \mathrm{~mm})$ and $\mathrm{O}+\mathrm{L}+\mathrm{Mg}(1.5 \mathrm{~mm})$ showed significantly lower diameter than FFP $(2.54 \mathrm{~mm})$. The root tips (RT) also improved considerably under INM practices compared with FFP. Besides, root nutrient contents (N, P, K, Ca, and Mg) also significantly improved under $\mathrm{O}+\mathrm{L}+\mathrm{M}$ and $\mathrm{O}+\mathrm{L}+\mathrm{Mg}$ over FFP. Similar trends of root growth and nutrients uptake were recorded in 2020. Overall, these findings suggest that INM plays a significant role in root development and nutrient uptake under acidic soil, which could be useful for maximizing crop productivity.
\end{abstract}

Keywords: root distribution; integrated nutrient management; root traits; root nutrients; acidic soil

\section{Introduction}

Citrus is one of the world's major fruit crops with global availability in over 140 countries, and China is one of the leading citrus-producing countries with an annual citrus production of $4406 \times 10^{4}$ tons [1,2]. Pomelo (Citrus grandis) is the third major type of citrus after Citrus reticulata and Citrus sinensis in China, with an average yield of $320 \times 10^{4}$ tons [3]. Pinghe County (Fujian Province, China) is recognized as the most famous area for pomelo production [3-5]. However, the long-term intensive or unbalanced fertilization has caused severe problems in the pomelo orchard, e.g., a decline in soil $\mathrm{pH}$ and $\mathrm{Mg}$ deficiency, etc. $[6,7]$. The root growth in acidic soils $(\mathrm{pH}<4-4.5)$ is inhibited by $\mathrm{Al}^{3+}$ toxicity with adverse effects on crop production [8]. Therefore, balanced fertilization is very important for pomelo orchards to develop the most suitable soil conditions for root growth. 
Recently, more emphasis has been given to the balanced fertilization strategy by reducing the usage of mineral fertilizers to improve crop quality, production, and uptake of nutrients [9]. The mineral fertilizers, especially nitrogen, phosphorus, and potassium, are essential for plant nutrition [10-12] and crop productivity [13,14]. However, an inappropriate or extensive application of fertilizers leads to severe problems of soil acidification [7,15], soil and water pollution [16,17], and greenhouse gas emissions [18,19]. Moreover, it leads to excessive and sudden plant growth with an insufficient root system to provide adequate mineral nutrients and water supply to the plant. Thus, the poor root structure results in reduced flowering and fruit production, leading to poor plant growth [20]. Furthermore, with the increasing cost of chemical fertilizers and growing concerns over the environmental impact of excessive fertilization, there has been increasing scrutiny on how nutrients should be managed on farms [21]. Hence, the selective and appropriate use of substrate is a crucial factor for high production.

Integrated nutrient management (INM) aims for optimal soil fertility and plant nutrition, increasing fertilizer input efficiency, decreasing environmental risks, and improving crop productivity through root/rhizosphere management [9]. Various models have been presented for sustainable soil management to increase the yield and produce nutritious and healthy products $[22,23]$. Regarding management methods, the application of organic and inorganic sources of nutrient elements has been used to obtain optimum productivity [9]. Therefore, finding innovative integrated nutrient management is a matter of great interest that could offset soil acidification and provide a healthy soil environment for plant roots to uptake the soil nutrients efficiently.

The root system plays an imperative role in crop yield because it performs essential functions for the plant, including water uptake, nutrients acquisition, and anchoring into the soil system $[24,25]$. It has been found that changes in the soil microenvironments (e.g., soil moisture, temperature, fertility, mechanical strength, and soil porosity, etc.) affect the growth of plant roots [26]. Various studies on the horticultural and agricultural systems have revealed how organic and inorganic amendments affect plant growth and root morphological characteristics [27,28]. However, research on the effects of N.P.K fertilizers amendments with lime, mushroom extract, and $\mathrm{Mg}$ fertilizer on tree growth, particularly on root morphological traits, is rare. Lime is recognized as an effective measure to improve the soil $\mathrm{pH}$ and has a beneficial effect on root growth [29]. It has also been found that mushroom residue improves soil structure and has a substantial impact on increasing soil $\mathrm{pH}$. However, $\mathrm{Mg}$ deficiency usually occurs in the acidic soils of China because a decrease in soil $\mathrm{pH}$ is coupled with deficiencies in soil exchangeable $\mathrm{Mg}[30,31]$. Therefore, it would be of great interest to investigate the combined effects of NPK fertilizer with lime, mushroom residue, and $\mathrm{Mg}$ fertilizer on root growth. Thus, measurement of root morphological traits such as root length, root surface area, root diameter, etc. are indispensable to broaden the understanding of plant physiological functions. For instance, root length is considered as the most important indicator that controls the water and nutrients acquisition, as well as the primary indicator of plant response to changing environmental conditions [32,33], whereas, root diameter is the beneficial indicator for the increase in biomass [34]. Hence, the knowledge of rooting patterns is an important aspect of crop production because it gives background information for the efficient use of fertilizer. Consequently, root traits have always been a critical target for researchers and breeders for crop improvement.

So far, analyzing the root phenotype is particularly important for understanding the response of root characteristics to nutrient management and developing precise agricultural practices in the future. Therefore, the present study was aimed at comprehensive nutrient management for pomelo orchards prone to soil acidification to develop the most suitable soil conditions for root growth. However, to the best of our knowledge, this study, for the first time, investigated how INM based on inorganic N.P.K fertilizer combined with lime, mushroom residue, and $\mathrm{Mg}$ may affect the root growth and nutrients availability in the root system. We hypothesized that fertilizers reduction input plus lime, mushroom residue, and $\mathrm{Mg}$ application could construct a more reasonable root architecture in pomelo. 
Therefore, a two-year field experiment was conducted to compare the effects of INM with conventional nutrient management. The key objectives were (1) to investigate the impact of different INM on root morphological traits and (2) to identify the influence of varying INM on nutrient uptake via roots.

\section{Materials and Methods}

\subsection{Study Area}

Guanximiyou pomelo (Citrus grandis) orchard of Pinghe County $\left(24^{\circ} 02^{\prime}-24^{\circ} 35^{\prime} \mathrm{N}\right.$, $116^{\circ} 54^{\prime}-117^{\circ} 31^{\prime}$ E) located in the southern region of Fujian Province, was selected for this study. This area is characterized by a subtropical monsoon climate with average annual precipitation of about $1600-2000 \mathrm{~mm}$, temperature $17.5-21.3^{\circ} \mathrm{C}$. The soil type of this study area is classified as haplic ferralsols that are classified as red soil in the Chinese soil classification system and contains $39.2 \%$ sand, $35.8 \%$ silt, and $25.1 \%$ clay [35]. The basic soil properties are shown in Table 1.

Table 1. Soil physicochemical properties of the pomelo orchard (means \pm standard deviation, $n=3$ ).

\begin{tabular}{|c|c|c|c|c|c|c|c|}
\hline Soil Depth & \multirow{2}{*}{ pH } & Nitrate-N & Ammonium-N & Available-P & Available-K & Exchangeable-Ca & Exchangeable-Mg \\
\hline$(\mathrm{cm})$ & & (mg/kg) & (mg/kg) & (mg/kg) & (mg/kg) & (mg/kg) & (mg/kg) \\
\hline $\begin{array}{c}0-20 \\
20-40\end{array}$ & $4.6 \pm 0.4$ & $11.0 \pm 3.1$ & $45.7 \pm 14.8$ & $787.6 \pm 94.5$ & $341.0 \pm 87.8$ & $294.4 \pm 159.8$ & $92.8 \pm 37.1$ \\
\hline $20-40$ & $4.2 \pm 0.4$ & $6.0 \pm 1.8$ & $32.3 \pm 22.1$ & $509.9 \pm 116.0$ & $252.9 \pm 54.7$ & $260.0 \pm 121.0$ & $63.4 \pm 26.1$ \\
\hline
\end{tabular}

\subsection{Pomelo Root Spatial Distribution Survey and Analysis}

To check the spatial distribution of pommel root, we selected trees of different ages, i.e., $8,13,18$, and 23 years old. Root samples were collected horizontally at 20, 40, 60, 80, 100,120 , and $140 \mathrm{~cm}$ away from the tree trunk at $0-20$ and $20-40 \mathrm{~cm}$ soil depth vertically (Figure 1). Eight trees were selected for each age of the tree, and samples were collected using a soil core sampler ( $3 \mathrm{~cm}$ diameter). To reduce the plot damage, a borehole sampling method was used to collect the pomelo roots [36]. The roots were washed with deionized water and scanned with the scanner (Epson V800, China, Co., Ltd., Beijing, China). Root images were analyzed using WinRhizo software (Regent Instruments Inc., Quebec, QC, Canada) for diffident root morphological traits, including root length density (RLD), root surface area (RSA), and root diameter (RD).

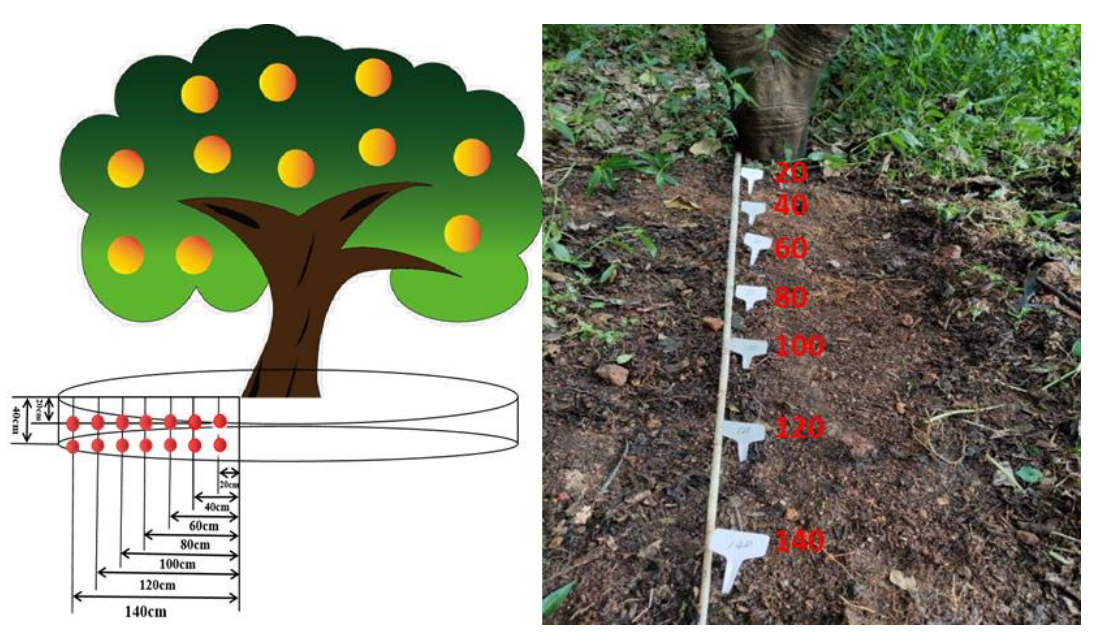

Figure 1. Collection of root samples for spatial distribution. The root samples were collected vertically from $0-20 \mathrm{~cm}$ and $20-40 \mathrm{~cm}$ soil profiles. For horizontal spatial root distribution, root samples were collected from 7 soil layers $(0-140 \mathrm{~cm}$, each at $20 \mathrm{~cm}$ interval) around the tree trunk. 


\subsection{Experimental Setup and Harvest}

As a result of the spatial root distribution survey, the pomelo trees were fertilized around $20-80 \mathrm{~cm}$ from the trunk for two consecutive years, i.e., 2019 and 2020. Based on different growth periods of pomelo, fertilization was applied at four different stages, i.e., February (shooting and flowering stage), April (fruit stabilizing stage), June (fruit expansion stage), and December (Table S1). For fertilization, we set up three treatments: (1) farmer fertilization practice (FFP), (2) optimization of N.P.K (O) by reducing the input, and combined with the application of lime $(\mathrm{L})$ and mushroom residue $(\mathrm{M})$ to control soil $\mathrm{pH}$, and called $\mathrm{O}+\mathrm{L}+\mathrm{M}$ treatment, (3) combination of $\mathrm{Mg}$ fertilizer with $\mathrm{O}+\mathrm{L}$ called as $\mathrm{O}+\mathrm{L}+\mathrm{Mg}$. The lime used in this study was hydrated lime, i.e., $\mathrm{Ca}(\mathrm{OH})_{2}$, in the form of fine powder. It is used to neutralize the soil acidity to obtain a desirable soil $\mathrm{pH}$ that supports plant growth. It was applied around the tree trunk at $20-80 \mathrm{~cm}$ (Figure S1). The mushroom residue was the waste material left after the production of mushrooms and obtained from Xiamen Jiangping Company, and chemical composition has been shown in Table S2. These were applied around the tree trunk at 75-125 cm in FFP, while at 20-80 $\mathrm{cm}$ in $\mathrm{O}+\mathrm{L}+\mathrm{M}$ (Figure S2). The fertilizers used in this study included urea $(46 \% \mathrm{~N})$, diammonium phosphate $(42 \%$ $\left.\mathrm{P}_{2} \mathrm{O}_{5}\right)$, potassium sulfate $\left(51 \% \mathrm{~K}_{2} \mathrm{O}\right)$, lime $(75 \% \mathrm{CaO})$, and magnesium sulfate monohydrate (27.5\% MgO). The fertilizer application rate is shown in Table 2.

Table 2. The application of fertilizers ( $\mathrm{kg} / \mathrm{ha})$.

\begin{tabular}{ccccccc}
\hline Treatment & $\mathbf{N}$ & $\mathbf{P}_{\mathbf{2}} \mathbf{O}_{\mathbf{5}}$ & $\mathbf{K}_{\mathbf{2}} \mathbf{O}$ & $\mathbf{M g O}$ & Lime & Mushroom Residue \\
\hline FFP & 1084 & 914 & 906 & 0 & 0 & 7700 \\
$\mathrm{O}+\mathrm{L}+\mathrm{M}$ & 160 & 0 & 176 & 0 & 3108 & 2000 \\
$\mathrm{O}+\mathrm{L}+\mathrm{Mg}$ & 200 & 0 & 200 & 40 & 3108 & 0 \\
\hline
\end{tabular}

Root samples were collected horizontally $50 \mathrm{~cm}$ away from the tree trunk at vertical 0-20 and 20-40 cm soil depth in June 2019 and 2020. The root samples were collected from two trees of each plot and composited as a representative sample for each treatment. Three plots were selected for each replication. The borehole sampling was deployed to obtain the pomelo root samples to minimize plot damage [36]. The roots were scanned with Epson V800, after being cleaned with deionized water. Root images were analyzed using WinRhizo software (Regent Instruments Inc., Quebec, QC, Canada) for diffident root morphological traits, i.e., root length (RL), root surface area (RSA), root diameter (RD), and the number of root tips (RT).

\subsection{Determination of Root Nutrient Contents}

The root samples were oven-dried $\left(70{ }^{\circ} \mathrm{C}, 48 \mathrm{~h}\right)$, and dry biomass was recorded. Root $\mathrm{N}, \mathrm{P}, \mathrm{K}, \mathrm{Ca}$, and $\mathrm{Mg}$ were extracted and measured according to the following Bao (2000) protocol [37]. For N, P, K, $0.05 \mathrm{~g}$ of the ground root sample was weighed and transferred to the digestion tube and $5 \mathrm{~mL}$ of concentrated sulfuric acid $\left(\mathrm{H}_{2} \mathrm{SO}_{4}\right)$ and $2.0 \mathrm{~mL}$ of hydrogen peroxide $\left(\mathrm{H}_{2} \mathrm{O}_{2}\right)$ were added. The digestion tubes were kept in the digestion block for approximately $4 \mathrm{~h}$, at a temperature of $200 \pm 20^{\circ} \mathrm{C}$ until obtaining clear digestion without the presence of particles, and then cooled at room temperature. The digested samples were transferred to a $100 \mathrm{~mL}$ volumetric flask, filled with $100 \mathrm{~mL}$ distilled water, and stored at $4{ }^{\circ} \mathrm{C}$ in a refrigerator until nutrients determination. For $\mathrm{Ca}$ and $\mathrm{Mg}$ determination, $0.10 \mathrm{~g}$ of the ground root sample was weighed and transferred to the conical flask, and $12 \mathrm{~mL}$ of nitric acid $\left(\mathrm{HNO}_{3}\right)$ : perchloric acid $\left(\mathrm{HClO}_{4}\right)$ in ratio 5:1 v/v was added. The digestion tubes were taken to the digestion block for approximately $3 \mathrm{~h}$, at a temperature of $200 \pm 20^{\circ} \mathrm{C}$ until obtaining a clear digest without the presence of particles. This procedure was performed in triplicate for each sample; solutions containing all the reagents were prepared analogously to be evaluated as a blank test. Total nitrogen was determined with a Skalar Flow Analyzer. Total potassium was determined with the Flame Photometer. Total phosphorus, magnesium, and calcium concentrations in the samples were determined 
using an inductively coupled plasma optical emission spectrometer (ICP-OES), and these solutions were filtered through a $0.4 \mu \mathrm{m}$ filter membrane before analysis.

\subsection{Statistical Analysis}

One-way analysis of variance was performed to analyze the effect of different treatments on root morphological traits. A $t$-test was performed to check whether root traits at different soil depths differed from each other. We performed the least significant difference $\left(\mathrm{LSD}_{0.05}\right)$ test to analyze the difference between the treatments using the SPSS 25.0 software (International Business Machines Corporation, New York, NY, USA).

\section{Results}

\subsection{Dynamic Spatial Root Distribution}

Root length density (RLD) showed significant spatial distribution patterns along with a horizontal soil profile and decreased significantly with increasing distance from the trunk for all ages. Overall, RLD was much higher in 0-80 cm than $140 \mathrm{~cm}$ (FFP), and FFP exhibited low root length density. Moreover, we found that RLD in the topsoil $(0-20 \mathrm{~cm})$ was much higher than in the subsoil $(20-40 \mathrm{~cm}$ ) (Figure 2a). Similarly, the horizontal spatial distribution of roots distribution also significantly affected the root surface area (RSA) for all tree ages. We found that RSA decreased with increasing distance from the trunk and showed the maximum RSA closer to the trunk $(20-80 \mathrm{~cm})$. Like RLD, the minimum RSA was recorded at a sampling point of $140 \mathrm{~cm}$, suggesting the poor reliability of farmer practice. Besides, the average RSA was higher in the topsoil over subsoil (Figure 2b). Root diameter (RD) was also significantly affected along with the horizontal spatial distribution. $\mathrm{RD}$ was substantially higher closer to the trunk at $0-80 \mathrm{~cm}$ and then gradually decreased and minimum RD was recorded at the $140 \mathrm{~cm}$ sampling point. Overall, the RD was higher in the topsoil compared with the subsoil (Figure 2c). Thus, root development along spatial distribution was much better in the $20-80 \mathrm{~cm}$ from the trunk and also in the topsoil of 0-20 cm (Figure 2d).

\subsection{Root Morphological Traits under Various Nutrients Management Practices}

The findings of the present study showed that INM significantly promoted the root morphological characteristics. Under different nutrient management practices, including $\mathrm{O}+\mathrm{L}+\mathrm{M}$ and $\mathrm{O}+\mathrm{L}+\mathrm{Mg}$, the roots' morphological traits improved significantly, i.e., root length (RL), root surface area (RSA), root diameter (RD), and root tips (RT) compared with farmer fertilizer practice.

RL was significantly $(p \leq 0.05)$ increased under $\mathrm{O}+\mathrm{L}+\mathrm{M}$ and $\mathrm{O}+\mathrm{L}+\mathrm{Mg}$ treatments compared with FFP along with vertical soil profile during 2019 and 2020 (Figure 3a). RL under the FFP was 28.97 and $28.75 \mathrm{~cm}$, and it was significantly increased by the application of $\mathrm{O}+\mathrm{L}+\mathrm{M}(108.48$ and $219.14 \mathrm{~cm})$ and $\mathrm{O}+\mathrm{L}+\mathrm{Mg}(73.58,66.81 \mathrm{~cm})$ for topsoil $(0-20 \mathrm{~cm})$ and subsoil $(20-40 \mathrm{~cm})$, respectively, in 2019 . Similar results were found during the preceding year-2020, and significant RL improvement was recorded (Figure 3a). The INM significantly $(p \leq 0.05)$ influenced the RSA, and $\mathrm{O}+\mathrm{L}+\mathrm{M}$ and $\mathrm{O}+\mathrm{L}+\mathrm{Mg}$ showed excellent results compared with FFP, i.e., $\mathrm{O}+\mathrm{L}+\mathrm{Mg}>\mathrm{O}+\mathrm{L}+\mathrm{M}>$ FFP. RSA in the topsoil was 7.98, $26.72,66.68 \mathrm{~cm}^{2}$ for the year 2019, while $54.48,161.65$, and $203.17 \mathrm{~cm}^{2}$ in 2020, at FFP, $\mathrm{O}+\mathrm{L}+\mathrm{M}$, and $\mathrm{O}+\mathrm{L}+\mathrm{Mg}$, respectively. Furthermore, the spatial distribution of roots showed a relatively higher average RSA in the topsoil compared with subsoil during 2019 and 2020 (Figure 3b). For average RD, the pomelo trees treated with $\mathrm{O}+\mathrm{L}+\mathrm{M}(0.81 \mathrm{~mm})$ and $\mathrm{O}+\mathrm{L}+\mathrm{Mg}(1.49 \mathrm{~mm})$ reduced their diameters significantly compared to FFP $(2.54 \mathrm{~mm})$ in the topsoil during 2019, and a similar trend was recorded for subsoil in the year 2020. The roots $\leq 2 \mathrm{~mm}$ in diameter have greater ability to uptake the nutrients. Hence, average RD was significantly decreased under the $\mathrm{O}+\mathrm{L}+\mathrm{M}$ and $\mathrm{O}+\mathrm{L}+\mathrm{Mg}$ (Figure 3c). Similar to RL, $\mathrm{RSA}$, and $\mathrm{RD}$, the RT was also improved considerably under the $\mathrm{O}+\mathrm{L}+\mathrm{M}$ and $\mathrm{O}+\mathrm{L}+\mathrm{Mg}$ treatments compared with FFP along with vertical soil profile during 2019 and 2020, but the maximum number of RT was found in the topsoil during both years (Figure 3d). Overall, 
these results imply that nutrient management practices had a significant effect on root development, especially in the topsoil compared with FFP.
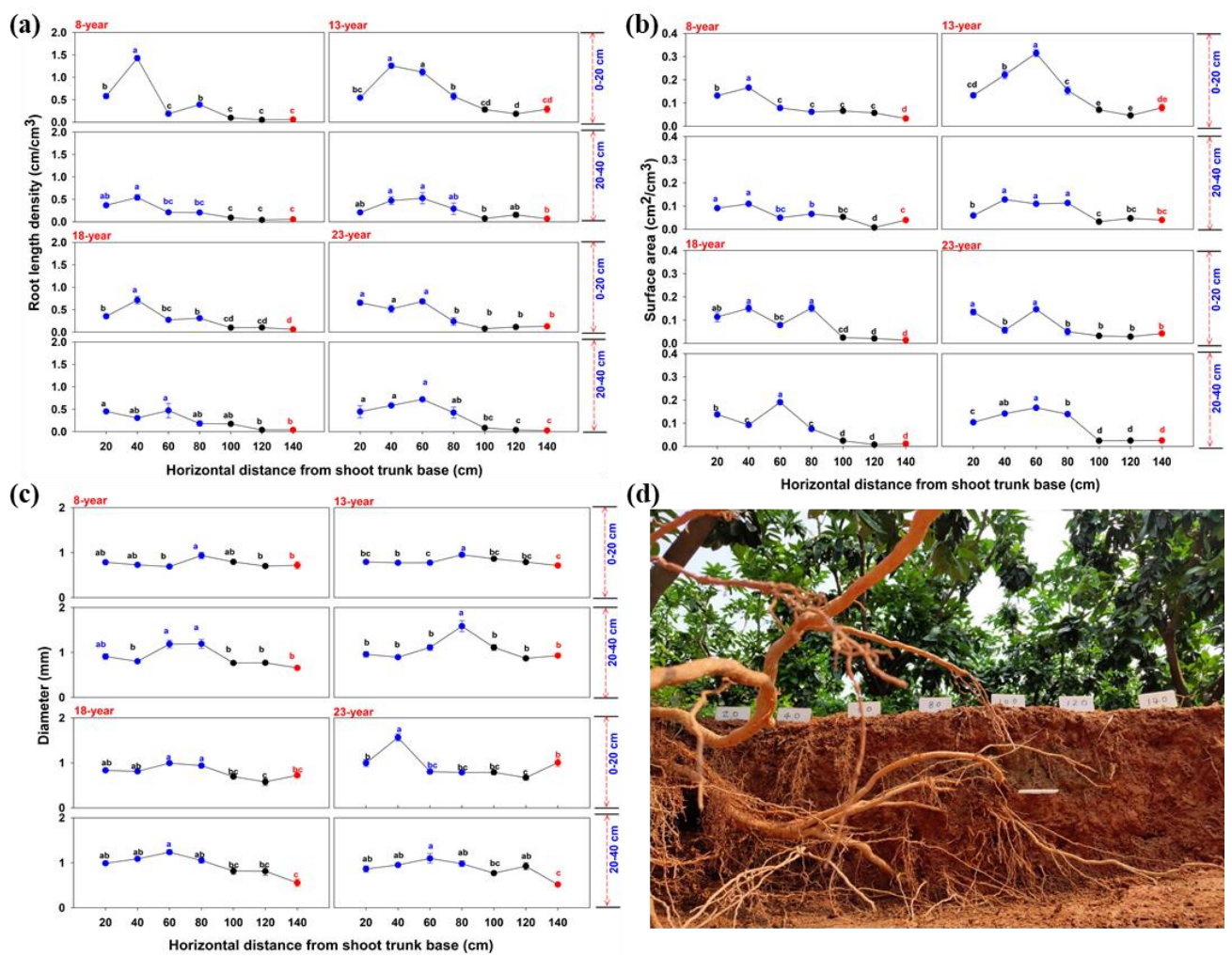

Figure 2. Spatial distribution of pomelo root growth under different tree ages. (a) Root length density; (b) root surface area; (c) root diameter, along the horizontal (20-140 cm) and vertical (0-20, $20-40 \mathrm{~cm}$ ) soil profile. The red dot at $140 \mathrm{~cm}$ is showing the farmer fertilizer practice zone of fertilizer application. Significant differences $(p<0.05)$ among different horizontal sampling points are shown by different letters, $n=8$; (d) Overall distribution pattern of pomelo root growth concentrated in $20-80 \mathrm{~cm}$.

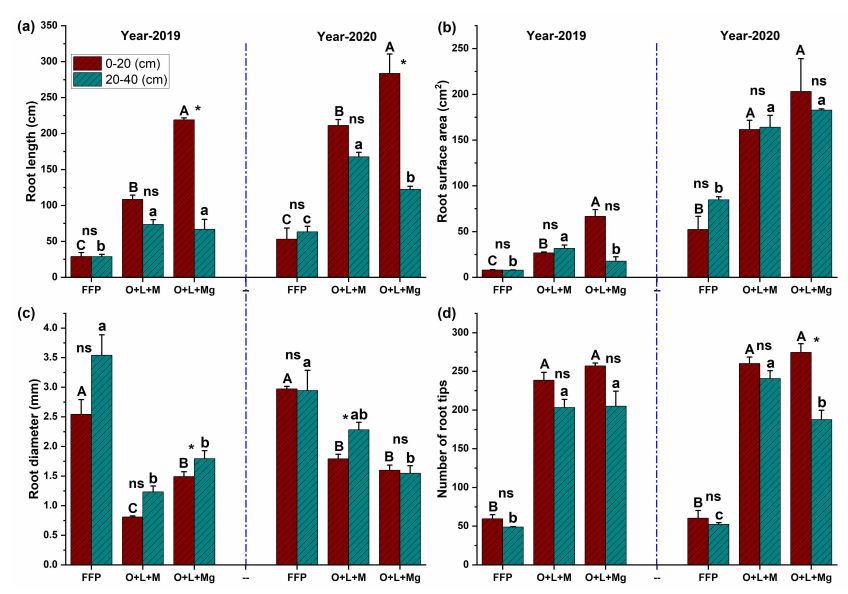

Figure 3. Root morphological traits under different nutrient management. (a) Root length; (b) root surface area; (c) root diameter; (d) root tips, along with the vertical soil profile, i.e., $0-20$ and $20-40 \mathrm{~cm}$ during 2019 and 2020. The alphabetic letters on the bars indicate a significant difference $\left(\mathrm{LSD}_{0.05}\right)$. The error bars represent the standard deviation of the mean $(n=3)$. The upper-case letters denote the significant differences for different treatments at $0-20 \mathrm{~cm}$, while the lower-case letters for $20-40 \mathrm{~cm}$ depth. The significant differences between the topsoil $(0-20 \mathrm{~cm})$ and subsoil $(20-40 \mathrm{~cm})$ are indicated by the symbol ${ }^{*}$, while ns denotes the non-significant differences $(n=3)$. 


\subsection{Root Nutrient Contents}

Compared with the FFP treatment, the $\mathrm{O}+\mathrm{L}+\mathrm{M}$ and $\mathrm{O}+\mathrm{L}+\mathrm{Mg}$ treatments significantly increased the $\mathrm{N}, \mathrm{P}, \mathrm{K}, \mathrm{Ca}$, and $\mathrm{Mg}$ contents in pomelo roots. In the $\mathrm{O}+\mathrm{L}+\mathrm{M}$ and $\mathrm{O}+\mathrm{L}+\mathrm{Mg}$ treatments, the reduced input of $\mathrm{N}, \mathrm{P}$, and $\mathrm{K}$ did not minimize root nutrient contents, while the root nutrient contents of $\mathrm{N}, \mathrm{P}, \mathrm{K}, \mathrm{Ca}$, and $\mathrm{Mg}$ increased significantly.

In 2019, root nutrient contents in topsoil were increased compared with the FFP, e.g., the total amount of $\mathrm{N}$ was increased $32.32 \%$ and $242.95 \%$, P was increased $64.07 \%$ and $187.76 \%$, $\mathrm{K}$ was increased $110.62 \%$ and $8.02 \%$, Ca was increased $89.97 \%$ and $158.37 \%$, and $\mathrm{Mg}$ was increased $239.51 \%$ and $85.49 \%$ for $\mathrm{O}+\mathrm{L}+\mathrm{M}$ and $\mathrm{O}+\mathrm{L}+\mathrm{Mg}$ treatments, respectively. Similarly, at $20-40 \mathrm{~cm}$, root nutrient contents were also increased in $\mathrm{O}+\mathrm{L}+\mathrm{M}$ and $\mathrm{O}+\mathrm{L}+\mathrm{Mg}$ treatments compared with FFP. Root nutrient contents at a soil depth of $0-20 \mathrm{~cm}$ were higher on average by $1.5 \%$ compared to $20-40 \mathrm{~cm}$. In 2020, the root nutrient contents were significantly increased for N $23.13 \%$ and $198.61 \%$; P was increased $139.10 \%$ and $74.89 \%$, $\mathrm{K}$ was increased $19.10 \%$ and $60.85 \%$; Ca was increased $44.49 \%$ and $32.96 \%$, and $\mathrm{Mg}$ was increased $97.57 \%$ and $35.45 \%$ under $\mathrm{O}+\mathrm{L}+\mathrm{M}$ and $\mathrm{O}+\mathrm{L}+\mathrm{Mg}$ treatments, respectively, compared with FFP treatment. Hence, the INM increased the root nutrient contents by $60 \%$ on average, while root nutrient contents at $0-20 \mathrm{~cm}$ were $1.8 \%$ higher than $20-40 \mathrm{~cm}$ (Figure 4). It implies that the nutrient management $(\mathrm{O}+\mathrm{L}+\mathrm{M}$ and $\mathrm{O}+\mathrm{L}+\mathrm{Mg})$ showed better results than FFP and also more root nutrient contents at $0-20 \mathrm{~cm}$ than $20-40 \mathrm{~cm}$. The INM significantly increased the root nutrient content, indicating that nutrients were fully utilized, and hence improved the nutrient availability under pomelo orchard.

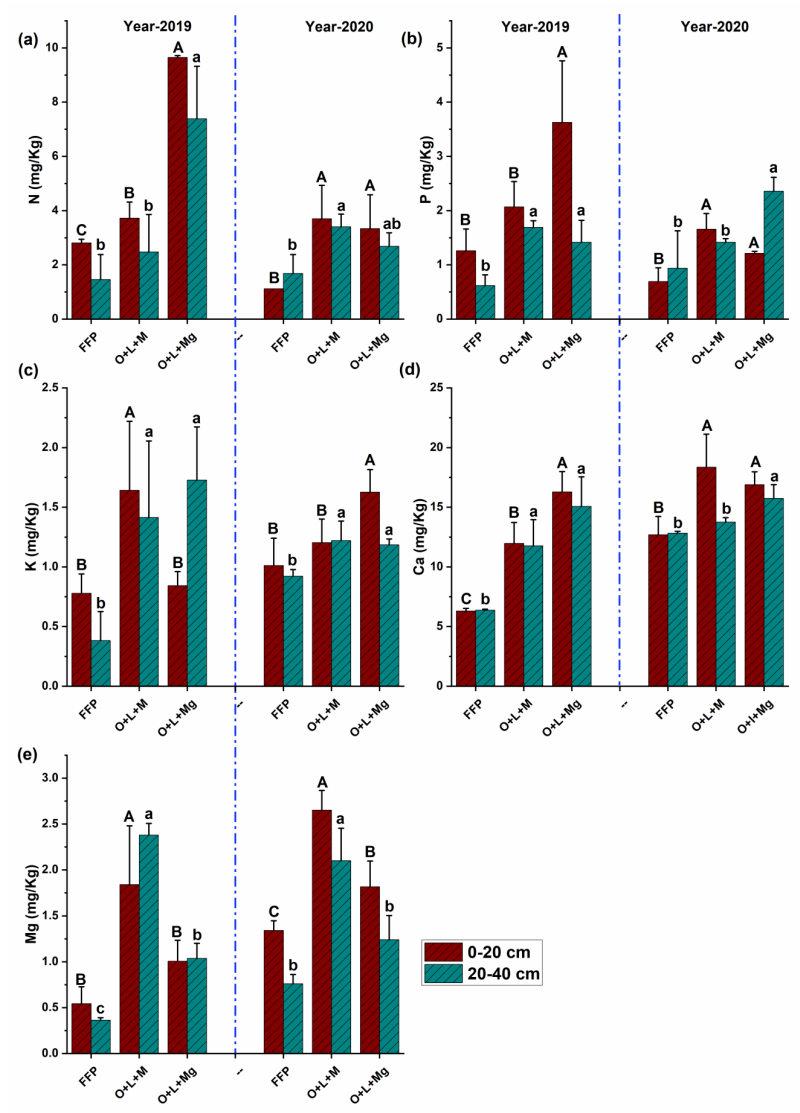

Figure 4. Nutrient management effects on root nutrient contents. (a) Nitrogen $(\mathrm{N} \mathrm{mg} / \mathrm{kg})$. (b) Phosphorous (P mg/kg). (c) Potassium (K mg/kg). (d) Calcium (Ca mg/kg). (e) Magnesium (Mg mg/kg) along with the vertical soil profile, i.e., 0-20 and 20-40 cm during 2019 and 2020. The alphabetic letters on the bars indicate a significant difference $\left(\mathrm{LSD}_{0.05}\right)$. The error bars represent the standard deviation of the mean $(n=3)$. The upper-case letters denote the significant differences for different treatments at $0-20 \mathrm{~cm}$, while the lower-case letters for $20-40 \mathrm{~cm}$ depth. 


\subsection{Relationship between Root Nutrient Contents and Morphological Traits}

The root nutrient contents of $\mathrm{N}, \mathrm{P}, \mathrm{K}, \mathrm{Ca}$, and $\mathrm{Mg}$ were generally positively correlated with root morphological traits, i.e., RL, RSA, and RT, while negatively correlated with RD during both 2019 and 2020 along with vertical soil profile of $0-20$ and $20-40 \mathrm{~cm}$ (Figure 5).

(a) 0-20 cm (2019)

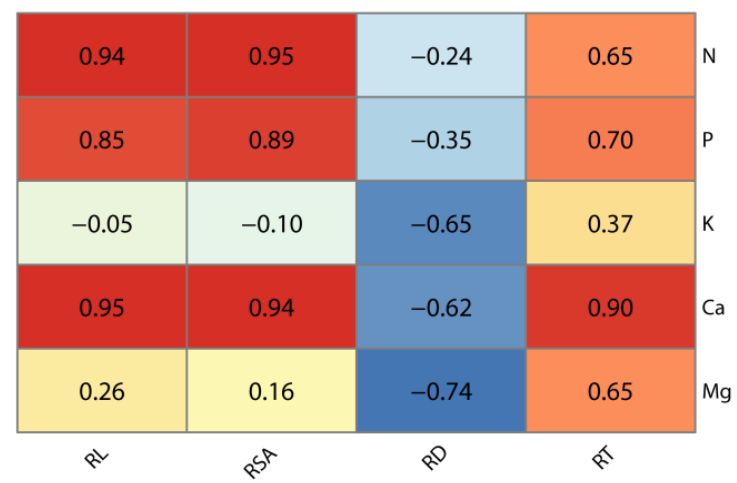

(b) $20-40 \mathrm{~cm}(2019)$

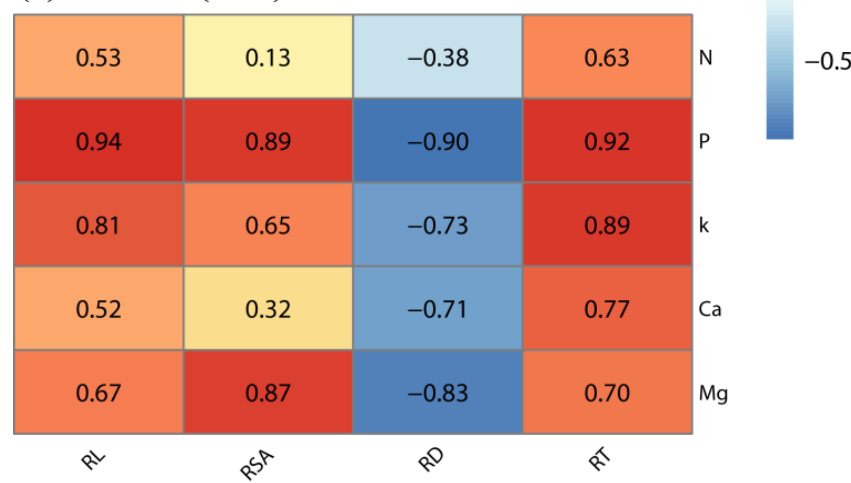

(c) $0-20 \mathrm{~cm}(2020)$

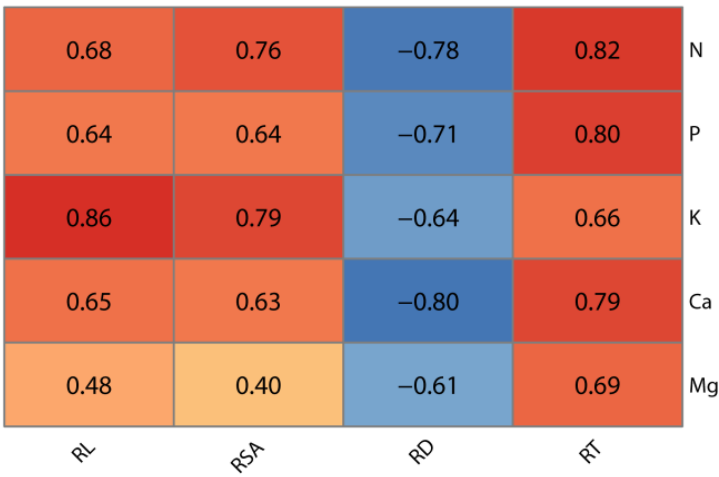

(d) $20-40 \mathrm{~cm}(2020)$

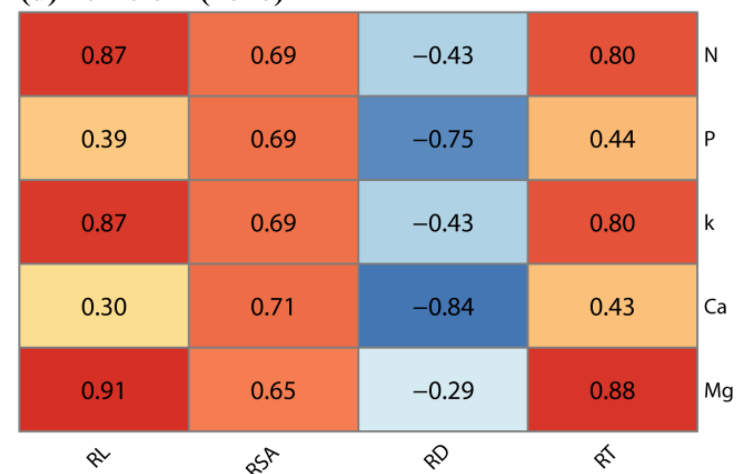

Figure 5. Linear correlation between root traits and nutrient contents. The correlation analysis was studied; (a,b) Year-2019 at 0-20 and 20-40 cm; (c,d) Year-2020 at 0-20 and 20-40 cm, between root morphological traits root length (RL), root surface area (RSA), root diameter (RD), root tips (RT), and root nutrient contents nitrogen $(\mathrm{N})$, phosphorous (P), potassium (K), calcium $(\mathrm{Ca})$, and magnesium $(\mathrm{Mg})$. The values indicate the correlation coefficients.

\section{Discussion}

Roots serve as the linkage between soil particles and plants, and their development has a substantial impact on plant nutrition [38]. Various studies imply that root morphological traits have a crucial influence on soil nutrient absorption [39-41]. As a consequence, understanding root development and dynamics are critical for determining the most effective nutrient management practices, allowing plant roots to absorb the nutrients efficiently and resulting in better plant growth $[42,43]$. Therefore, we conducted a systematic study in which first we assessed the development of pomelo root growth, and then based on the initial survey, we identified the impact of various nutrient management practices on root morphological characteristics and its nutrient absorption.

Plants can be fertilized either directly or indirectly; nevertheless, adequate amount, timing, area, and distribution of fertilizer are of prime importance $[38,44-46]$. In Pinghe county, we found that extensive application of N.P.K fertilizer at 75-125 cm away from the trunk (farmer fertilizer practice) resulted in various soil constraints, e.g., soil acidification (low $\mathrm{pH}$ ) that influences the nutrient's availability to the plants $[46,47]$. Therefore, in this study, first we surveyed the distribution of pomelo root growth and found that root growth was concentrated horizontally at $20-80 \mathrm{~cm}$ away from the trunk and vertically along 0-20 cm soil profile (Figure 2). Our results are in line with the previous findings 
of horticulture fruit trees of pear and citrus, suggesting that $86 \%$ of root growth was located at the horizontal distance of $80 \mathrm{~cm} \mathrm{[48-50]} \mathrm{and} \mathrm{vertically} \mathrm{concentrated} \mathrm{in} \mathrm{the} \mathrm{upper}$ $15 \mathrm{~cm}$ [51,52]. This might be owing to more nutrient availability in these soil layers due to more active biological cycling, and hence root growth is improved and provides more nutrients to the plant [53]. Thus, to check the effectiveness of different nutrient management practices, we reduced the N.P.K fertilizer and integrated it with lime, mushroom residue, and $\mathrm{Mg}$, e.g., $\mathrm{O}+\mathrm{L}+\mathrm{M}$ and $\mathrm{O}+\mathrm{L}+\mathrm{Mg}$ treatments, and we identified the impact on root traits.

As expected, the nutrient management $(\mathrm{O}+\mathrm{L}+\mathrm{M}$ and $\mathrm{O}+\mathrm{L}+\mathrm{Mg})$ improved the root growth traits (RL, RSA, RD, and RT) (Figure 3) and also root nutrient uptake (Figure 4) compared with FFP under acidic soils. The acidic soils are characterized by high soil acidity and low soil fertility [54], and soil acidification is one of the limiting factors that restrict plant growth and development in south China [55]. Therefore, we used the lime and mushroom residue to control the soil $\mathrm{pH}$ because it has been reported that liming with fertilization significantly improves the exchangeable $\mathrm{Ca}^{2+}$ and $\mathrm{Mg}^{2+}$, while decreasing the exchangeable $\mathrm{Al}^{3+}[56,57]$ and promoting the absorption of nutrient elements in the pomelo trees in the topsoil [58-60]. Our results agree with those of Hailing et al. (2010), who affirmed liming with fertilization improves the root morphological traits $[56,57,61]$. Besides, the mushroom residue also significantly improved the root architecture of the pomelo tree and this is consistent with previous findings [62,63]. Mushroom residues contain a significant number of essential nutrients for plant growth that have been reported in previous studies $[64,65]$, and they improve the soil organic matter, quality, and $\mathrm{pH}[15,63]$. Consequently, better nutrient availability resulted in improved root morphological traits under various nutrient management practices and could play an important role in increasing the pomelo yield under acidic soils of southern China.

$\mathrm{Mg}$ is primarily absorbed by plants through their root system, and its availability is significantly influenced by soil acidification, e.g., a decrease in soil $\mathrm{pH}$ is coupled with deficiency in soil exchangeable $\mathrm{Mg}[66,67]$. However, its mobility is susceptible to leaching in the soil profile, especially in the acidic soil with high precipitation [68]. It has been reported that liming eliminates the detrimental effects of soil acidification and improves the $\mathrm{Mg}$ availability and Mg fertilizer use efficiency [69]. Mg application into the soil is thought to be an effective nutrient management practice to improve the soil Mg concentration due to its vital role in photosynthesis, plant growth, and root traits [70]. We found that $\mathrm{Mg}$ application significantly improved the pomelo root growth and nutrient uptake. These results are similar to previous findings where the application of $\mathrm{Mg}$ significantly improved the root morphological attributes [71-73]. It could be explained that $\mathrm{Mg}$ fertilizer may improve chlorophyll synthesis and result in glucose production. So, these biochemical attributes are utilized by the plant roots in the respiration process. As a result, root growth traits (root length and root surface area) are improved and facilitate the nutrient uptake by roots in plants [74]. Root length is indeed one of the most frequently measured parameters, primarily due to its significance as a general, standardized predictor of plant response to environmental factors [33], because of its role in the transport of nutrients and water [32]. In addition, we found that root diameter $(<2 \mathrm{~mm})$ decreased under integrated management practices, and it has been well established that roots $<2 \mathrm{~mm}$ favor the higher respiration rate [75], which favors the improved root growth and nutrient uptake [74]. The root surface area and root tips improved under INM possibly due to the synthesis of biochemical attributes under efficient nutrient uptake by roots and were supposed to be favorable for biomass production [34,74]. Hence, these root traits could not be improved under severely $\mathrm{Mg}$ deficient soils. Therefore, integrated nutrient management showed significant results in improving the pomelo root growth and enhanced root nutrient availability like N, P, K, $\mathrm{Ca}$, and $\mathrm{Mg}$.

\section{Conclusions}

This study first investigated the pomelo rooting growth patterns along with vertical and horizontal soil profiles. We found that root growth was more active and concentrated 
at the top vertical soil profile of 0-20 cm compared with $20-40 \mathrm{~cm}$, while horizontally, the root growth and development was better at $20-80 \mathrm{~cm}$ from the tree trunk. Thus, we applied different treatments $(\mathrm{O}+\mathrm{L}+\mathrm{M}$ and $\mathrm{O}+\mathrm{L}+\mathrm{Mg})$ in the active root growth zone, i.e., $20-80 \mathrm{~cm}$, and compared with farmer fertilization practice. We found that nutrient management, including lime, mushroom residue, and $\mathrm{Mg}$ fertilizer with optimized input of N.P.K fertilizers, significantly improved the root morphological traits, i.e., root length, root surface area, root diameter, and root tips compared with the farmer fertilization practice. It also resulted in improved root nutrient uptake, e.g., such as $\mathrm{N}, \mathrm{P}, \mathrm{K}, \mathrm{Ca}$, and $\mathrm{Mg}$, and we found a positive correlation between the root morphological traits and root nutrient uptake. Therefore, the application of optimized N.P.K fertilizer combined with lime, mushroom residue, and $\mathrm{Mg}$ fertilizer is an effective approach in the acidic and $\mathrm{Mg}$-deficient pomelo orchards to develop healthy and sustainable orchards by means of improving the root growth and its nutrient uptake. However, it is imperative to further investigate the effects of nutrient management on pomelo yield, quality, and socioeconomic benefits.

Supplementary Materials: The following are available online at https:/ / www.mdpi.com/article/10 .3390 /agronomy11061231/s1.

Author Contributions: Methodology, formal analysis, writing-original draft preparation, X.H. and M.A.M.; validation, software; J.L. and W.H., visualization, formal analysis, C.M., J.J. and Y.C.; X.C. data curation and investigation; Conceptualization, writing-review and editing, L.W., Conceptualization, supervision, writing-review and editing, C.Z. All authors have read and agreed to the published version of the manuscript.

Funding: This research was funded by National Natural Science Foundation of China (41601244) and Open Research Foundation of International Magnesium Institute (IMI2018-09).

Acknowledgments: Sincere gratitude to Xinming Lin for providing pomelo orchards, Yadong Zhang, Jinchang Yang, Weiqiang Zhang, and Kaiyue Xu for samples collection, Xizi Xia, Juanyan Li, Jing Luo, Haoran Jia, and Mingyi Peng for sample pretreatment, and Chunjian Li for providing useful guidance to improve the study.

Conflicts of Interest: The authors declare no conflict of interest.

\section{References}

1. Chen, X.; Xu, X.; Lu, Z.; Zhang, W.; Yang, J.; Hou, Y.; Wang, X.; Zhou, S.; Li, Y.; Wu, L.; et al. Carbon footprint of a typical pomelo production region in China based on farm survey data. J. Clean. Prod. 2020, 277, 124041. [CrossRef]

2. Citrus Fruit Production by Country. 2020. Available online: https:// knoema.com/ (accessed on 20 May 2021).

3. Li, Y.; Han, M.-Q.; Lin, F.; Ten, Y.; Lin, J.; Zhu, D.-H.; Guo, P.; Weng, Y.B.; Chen, L.-S. Soil chemical properties, 'Guanximiyou'pummelo leaf mineral nutrient status and fruit quality in the southern region of Fujian province, China. J. Soil Sci. Plant Nutr. 2015, 15, 615-628.

4. Guo, J.; Yang, J.; Zhang, L.; Chen, H.; Jia, Y.; Wang, Z.; Wang, D.; Liao, W.; Chen, L.-S.; Li, Y. Lower soil chemical quality of pomelo orchards compared with that of paddy and vegetable fields in acidic red soil hilly regions of southern China. J. Soils Sediments 2019, 19, 2752-2763. [CrossRef]

5. Yan, X.; Yang, W.; Muneer, M.A.; Zhang, S.; Wang, M.; Wu, L. Land-use change affects stoichiometric patterns of soil organic carbon, nitrogen, and phosphorus in the red soil of Southeast China. J. Soils Sediments 2021. [CrossRef]

6. Zeng, M.; de Vries, W.; Bonten, L.T.C.; Zhu, Q.; Hao, T.; Liu, X.; Xu, M.; Shi, X.; Zhang, F.; Shen, J. Model-based analysis of the long-term effects of fertilization management on cropland soil acidification. Environ. Sci. Technol. 2017, 51, 3843-3851. [CrossRef] [PubMed]

7. Guo, J.H.; Liu, X.J.; Zhang, Y.; Shen, J.L.; Han, W.X.; Zhang, W.F.; Christie, P.; Goulding, K.W.T.; Vitousek, P.M.; Zhang, F.S. Significant acidification in major chinese croplands. Science 2010, 327, 1008-1010. [CrossRef]

8. Haling, R.E.; Simpson, R.J.; Delhaize, E.; Hocking, P.J.; Richardson, A.E. Effect of lime on root growth, morphology and the rhizosheath of cereal seedlings growing in an acid soil. Plant Soil 2010, 327, 199-212. [CrossRef]

9. Murillo-Amador, B.; Morales-Prado, L.E.; Troyo-Diéguez, E.; Córdoba-Matson, M.V.; Hernández-Montiel, L.G.; Rueda-Puente, E.O.; Nieto-Garibay, A. Changing environmental conditions and applying organic fertilizers in Origanum vulgare L. Front. Plant Sci. 2015, 6, 549. [CrossRef]

10. Muneer, M.A.; Wang, P.; un Nisa, Z.; Lin, C.; Ji, B. Potential role of common mycorrhizal networks in improving plant growth and soil physicochemical properties under varying nitrogen levels in a grassland ecosystem. Glob. Ecol. Conserv. 2020, $24, \mathrm{e} 01352$. [CrossRef] 
11. Mantovani, J.R.; da Silveira, L.G.; Landgraf, P.R.C.; dos Santos, A.R.; Costa, B.D.S. Phosphorus rates and use of cattle manure in potted gerbera cultivation. Ornam. Hortic. 2017, 23, 412-418. [CrossRef]

12. Muneer, M.A.; Wang, P.; Zhang, J.; Li, Y.; Munir, M.Z.; Ji, B. Formation of Common Mycorrhizal Networks Significantly Affects Plant Biomass and Soil Properties of the Neighboring Plants under Various Nitrogen Levels. Microorganisms 2020, 8, 230. [CrossRef] [PubMed]

13. Yousaf, M.; Li, J.; Lu, J.; Ren, T.; Cong, R.; Fahad, S.; Li, X. Effects of fertilization on crop production and nutrient-supplying capacity under rice-oilseed rape rotation system. Sci. Rep. 2017, 7, 1270. [CrossRef] [PubMed]

14. Feng, J.; Hussain, H.A.; Hussain, S.; Shi, C.; Cholidah, L.; Men, S.; Ke, J.; Wang, L. Optimum Water and Fertilizer Management for Better Growth and Resource Use Efficiency of Rapeseed in Rainy and Drought Seasons. Sustainability 2020, 12, 703. [CrossRef]

15. Tian, D.; Niu, S. A global analysis of soil acidification caused by nitrogen addition. Environ. Res. Lett. 2015. [CrossRef]

16. Tang, W.; Shan, B.; Zhang, H.; Mao, Z. Heavy metal sources and associated risk in response to agricultural intensification in the estuarine sediments of Chaohu Lake Valley, East China. J. Hazard. Mater. 2010, 176, 945-951. [CrossRef]

17. Ju, X.-T.; Xing, G.-X.; Chen, X.-P.; Zhang, S.-L.; Zhang, L.-J.; Liu, X.-J.; Cui, Z.-L.; Yin, B.; Christie, P.; Zhu, Z.-L. Reducing environmental risk by improving $\mathrm{N}$ management in intensive Chinese agricultural systems. Proc. Natl. Acad. Sci. USA 2009, 106, 3041-3046. [CrossRef]

18. Chen, X.; Ma, C.; Zhou, H.; Liu, Y.; Huang, X.; Wang, M.; Cai, Y.; Su, D.; Muneer, M.A.; Guo, M.; et al. Identifying the main crops and key factors determining the carbon footprint of crop production in China, 2001-2018. Resour. Conserv. Recycl. 2021, 172, 105661. [CrossRef]

19. Tarin, M.W.K.; Khaliq, M.A.; Fan, L.; Xie, D.; Tayyab, M.; Chen, L.; He, T.; Rong, J.; Zheng, Y. Divergent consequences of different biochar amendments on carbon dioxide $\left(\mathrm{CO}_{2}\right)$ and nitrous oxide $\left(\mathrm{N}_{2} \mathrm{O}\right)$ emissions from the red soil. Sci. Total Environ. 2021, 754, 141935. [CrossRef] [PubMed]

20. Smith, K. The Perils of Over-Fertilizing Plants and Trees. Available online: http://mgeldorado.ucanr.edu/files/170168.pdf (accessed on 20 May 2021).

21. Chen, X.; Cui, Z.; Fan, M.; Vitousek, P.; Zhao, M.; Ma, W.; Wang, Z.; Zhang, W.; Yan, X.; Yang, J. Producing more grain with lower environmental costs. Nature 2014, 514, 486-489. [CrossRef]

22. Awad, F.; Khalil, K.W.; Maksoud, M.A. Comparative effects of some organic manures and bentonite as soil amendments. Agrochimica 1993, 37, 369-387.

23. Tahat, M.M.; Alananbeh, K.M.; Othman, Y.A.; Leskovar, D.I. Soil health and sustainable agriculture. Sustainability 2020, $12,4859$. [CrossRef]

24. Correa, J.; Postma, J.A.; Watt, M.; Wojciechowski, T. Soil compaction and the architectural plasticity of root systems. J. Exp. Bot. 2019, 70, 6019-6034. [CrossRef]

25. Smith, S.; De Smet, I. Root System Architecture: Insights from Arabidopsis and Cereal Crops; Royals Society: London, UK, 2012; pp. 1441-1452.

26. Freschet, G.T.; Valverde-Barrantes, O.J.; Tucker, C.M.; Craine, J.M.; McCormack, M.L.; Violle, C.; Fort, F.; Blackwood, C.B.; Urban-Mead, K.R.; Iversen, C.M. Climate, soil and plant functional types as drivers of global fine-root trait variation. J. Ecol. 2017, 105, 1182-1196. [CrossRef]

27. Chung, Y.S.; Kim, S.; Park, C.; Na, C.; Kim, Y. Treatment with silicon fertilizer induces changes in root morphological traits in soybean (Glycine max L.) during early growth. J. Crop Sci. Biotechnol. 2020, 23, 445-451. [CrossRef]

28. Zhang, Z.; Dong, X.; Wang, S.; Pu, X. Benefits of organic manure combined with biochar amendments to cotton root growth and yield under continuous cropping systems in Xinjiang, China. Sci. Rep. 2020, 10, 4718. [CrossRef] [PubMed]

29. Fageria, N.K.; Moreira, A. The role of mineral nutrition on root growth of crop plants. Adv. Agron. 2011, 110, $251-331$.

30. Chen, Z.C.; Peng, W.T.; Li, J.; Liao, H. Functional dissection and transport mechanism of magnesium in plants. In Proceedings of the Seminars in Cell \& Developmental Biology; Elsevier: Amsterdam, The Netherlands, 2018; Volume 74, pp. 142-152.

31. Wen, M.; Wu, S.; Wang, P.; Jin, G.; Zhu, X.; Shi, X. Effect of magnesium (Mg) application in Satsuma Mandarin orchard with Mg nutrient deficiency. J. Fruit Sci. 2015, 32, 63-68.

32. Clothier, B.E.; Green, S.R. Roots: The big movers of water and chemical in soil. Soil Sci. 1997, 162, 534-543. [CrossRef]

33. Edwards, E.J.; Benham, D.G.; Marland, L.A.; Fitter, A.H. Root production is determined by radiation flux in a temperate grassland community. Glob. Chang. Biol. 2004, 10, 209-227. [CrossRef]

34. Eissenstat, D.M.; Yanai, R.D. The ecology of root lifespan. In Advances in Ecological Research; Elsevier: Amsterdam, The Netherlands, 1997; Volume 27, pp. 1-60, ISBN 0065-2504.

35. Smith, D.W. Soil Survey Staff: Keys to Soil Taxonomy; USDA-Natural Resources Conservation Service: Washington, DC, USA, 2014.

36. Junying, L.; Baochun, F.; Yingchun, M. A review of researches and methods for fine-root production and Turnover of Trees. J. Shanxi Agric. Univ. 2006, 26, 1-6.

37. Bao, S.D. Soil and Agricultural Chemistry Analysis; China Agricultural Press: Beijing, China, 2000; pp. 30-34. (In Chinese)

38. Morgan, J.Á.; Connolly, E.Á. Plant-soil interactions: Nutrient uptake. Nat. Educ. Knowl. 2013, 4, 2.

39. López-Bucio, J.; Cruz-Ramirez, A.; Herrera-Estrella, L. The role of nutrient availability in regulating root architecture. Curr. Opin. Plant Biol. 2003, 6, 280-287. [CrossRef]

40. Yang, C.; Yang, L.; Yang, Y.; Ouyang, Z. Rice root growth and nutrient uptake as influenced by organic manure in continuously and alternately flooded paddy soils. Agric. Water Manag. 2004, 70, 67-81. [CrossRef] 
41. Wang, H.; Inukai, Y.; Yamauchi, A. Root development and nutrient uptake. CRC Crit. Rev. Plant Sci. 2006, 25, 279-301. [CrossRef]

42. Barber, S.A.; Silberbush, M. Plant root morphology and nutrient uptake. Roots Nutr. Water Influx Plant Growth 1984, 49 , 65-87.

43. Baligar, V.C.; Fageria, N.K.; He, Z.L. Nutrient use efficiency in plants. Commun. Soil Sci. Plant Anal. 2001, 32, 921-950. [CrossRef]

44. Zekri, M.; Schumann, A.W.; Vashisth, T.; Kadyampakeni, D.; Morgan, K.T.; Boman, B.; Obreza, T.A. 2020-2021 Florida Citrus Production Guide: Fertilizer Application Methods. EDIS 2020. [CrossRef]

45. Roberts, T.L. Right product, right rate, right time and right place ... the foundation of best management practices for fertilizer. Fertil. Best Manag. Pr. 2007, 29, 1-8.

46. Quiñones, A.; Martínez-Alcántara, B.; Primo-Millo, E.; Legaz, F. Fertigation: Concept and application in citrus. In Advances in Citrus Nutrition; Springer: Berlin/Heidelberg, Germany, 2012; pp. 281-301.

47. Long, A.; Zhang, J.; Yang, L.-T.; Ye, X.; Lai, N.-W.; Tan, L.-L.; Lin, D.; Chen, L.-S. Effects of low pH on photosynthesis, related physiological parameters, and nutrient profiles of citrus. Front. Plant Sci. 2017, 8, 185. [CrossRef]

48. Machado, B.D.; Magro, M.; de Souza, D.S.; Rufato, L.; Kretzschmar, A.A. Study on the growth and spatial distribution of the root system of different european pear cultivars on quince rootstock combinations. Rev. Bras. Frutic. 2018, 40. [CrossRef]

49. Santana, M.B.; Souza, L.d.S.; Souza, L.D.; Fontes, L.E.F. Soil physical attributes and citrus root system distribution as indicators of cohesive layers in soils of coastal table lands in the state of Bahia, Brazil. Rev. Bras. Ciênc. Solo 2006, 30, 1-12. [CrossRef]

50. Sun, W.T.; Ma, M.; Dong, T.; Liu, X.L.; Zhao, M.X.; Yin, X.N.; Niu, J.Q. Response of distribution pattern and physiological characteristics of apple roots grown in the dry area of eastern Gansu to ground mulching. Ying Yong Sheng Tai Xue Bao J. Appl. Ecol. 2016, 27, 3153-3163.

51. Spiers, J.M. Root Distribution ofGulfcoast'Southern Highbush Blueberry. HortScience 1997, 32, 428A. [CrossRef]

52. Xi, B.; Wang, Y.; Jia, L.; Bloomberg, M.; Li, G.; Di, N. Characteristics of fine root system and water uptake in a triploid Populus tomentosa plantation in the North China Plain: Implications for irrigation water management. Agric. Water Manag. 2013, 117, 83-92. [CrossRef]

53. Van der Heijden, G.; Dambrine, E.; Pollier, B.; Zeller, B.; Ranger, J.; Legout, A. Mg and Ca uptake by roots in relation to depth and allocation to aboveground tissues: Results from an isotopic labeling study in a beech forest on base-poor soil. Biogeochemistry 2015, 122, 375-393. [CrossRef]

54. Von Uexküll, H.R.; Mutert, E. Global extent, development and economic impact of acid soils. Plant Soil 1995, 171, 1-15. [CrossRef]

55. Cai, Z.; Wang, B.; Xu, M.; Zhang, H.; He, X.; Zhang, L.; Gao, S. Intensified soil acidification from chemical N fertilization and prevention by manure in an 18-year field experiment in the red soil of southern China. J. Soils Sediments 2015, 15, 260-270. [CrossRef]

56. Qaswar, M.; Dongchu, L.; Jing, H.; Tianfu, H.; Ahmed, W.; Abbas, M.; Lu, Z.; Jiangxue, D.; Khan, Z.H.; Ullah, S.; et al. Interaction of liming and long-term fertilization increased crop yield and phosphorus use efficiency (PUE) through mediating exchangeable cations in acidic soil under wheat-maize cropping system. Sci. Rep. 2020, 10, 19828. [CrossRef]

57. Han, T.; Cai, A.; Liu, K.; Huang, J.; Wang, B.; Li, D.; Qaswar, M.; Feng, G.; Zhang, H. The links between potassium availability and soil exchangeable calcium, magnesium, and aluminum are mediated by lime in acidic soil. J. Soils Sediments 2019. [CrossRef]

58. Álvarez, E.; Viadé, A.; Fernández-Marcos, M.L. Effect of liming with different sized limestone on the forms of aluminium in a Galician soil (NW Spain). Geoderma 2009, 152, 1-8. [CrossRef]

59. Aye, N.S.; Sale, P.W.G.; Tang, C. The impact of long-term liming on soil organic carbon and aggregate stability in low-input acid soils. Biol. Fertil. Soils 2016, 52, 697-709. [CrossRef]

60. Korzune, M.; Ávila, F.W.; Botelho, R.V.; Petranski, P.H.; de Matos, K.K.B.L.; Rampim, L.; Muller, M.M.L. Nutrient concentrations in trifoliate orange as affected by lime and gypsum. Res. Soc. Dev. 2020, 9, e7449109096. [CrossRef]

61. Trinchera, A.; Torrisi, B.; Allegra, M.; Rinaldi, S.; Rea, E.; Intrigliolo, F.; Roccuzzo, G. Effects of organic fertilization on soil organic matter and root morphology and density of orange trees. Acta Hortic 2015, 1065, 1807-1814. [CrossRef]

62. Uzun, I. Use of Spent Mushroom Compost in Sustainable Fruit Production. J. Fruit Ornam. Plant Res. 2004, 12, 157-165.

63. Oei, P.; Hui, Z.; Jianhua, L.; Jianqing, D.; Meiyuan, C.; Yi, C. The Alternative Uses of Spent Mushroom Compost; Oei, P., Ed.; Productschap Tuinbouw: Tiel, The Netherlands, 2007.

64. Fan, R.; Luo, J.; Gao, Y.; Liu, H.; Yan, S.; Zhang, Z. Advances in utilization of agricultural wastes in soilless growing medium production. Jiangsu J. Agric. Sci. 2014, 30, 442-448.

65. Kulshreshtha, S.; Mathur, N.; Bhatnagar, P. Mushroom as a product and their role in mycoremediation. AMB Express 2014, 4, 29. [CrossRef]

66. Chan, K.Y.; Davey, B.G.; Geering, H.R. Adsorption of Magnesium and Calcium by a Soil with Variable Charge. Soil Sci. Soc. Am. J. 1979, 43, 301-304. [CrossRef]

67. Cremer, M.; Prietzel, J. Soil acidity and exchangeable base cation stocks under pure and mixed stands of European beech, Douglas fir and Norway spruce. Plant Soil 2017, 415, 393-405. [CrossRef]

68. Gransee, A.; Führs, H. Magnesium mobility in soils as a challenge for soil and plant analysis, magnesium fertilization and root uptake under adverse growth conditions. Plant Soil 2013, 368, 5-21. [CrossRef]

69. Holland, J.E.; Bennett, A.E.; Newton, A.C.; White, P.J.; McKenzie, B.M.; George, T.S.; Pakeman, R.J.; Bailey, J.S.; Fornara, D.A.; Hayes, R.C. Liming impacts on soils, crops and biodiversity in the UK: A review. Sci. Total Environ. 2018, 610-611, 316-332. [CrossRef] [PubMed]

70. Gerendás, J.; Führs, H. The significance of magnesium for crop quality. Plant Soil 2013, 368, 101-128. [CrossRef] 
71. Cakmak, I.; Hengeler, C.; Marschner, H. Partitioning of shoot and root dry matter and carbohydrates in bean plants suffering from phosphorus, potassium and magnesium deficiency. J. Exp. Bot. 1994, 45, 1245-1250. [CrossRef]

72. Cakmak, I.; Hengeler, C.; Marschner, H. Changes in phloem export of sucrose in leaves in response to phosphorus, potassium and magnesium deficiency in bean plants. J. Exp. Bot. 1994, 45, 1251-1257. [CrossRef]

73. Zhang, J.; Li, B.; Zhang, J.; Christie, P.; Li, X. Organic fertilizer application and Mg fertilizer promote banana yield and quality in an Udic Ferralsol. PLoS ONE 2020, 15, e0230593. [CrossRef] [PubMed]

74. Tarin, M.W.K.; Fan, L.L.; Shen, L.; Lai, J.L.; Tayyab, M.; Sarfraz, R.; Chen, L.Y.; Ye, J.; He, T.Y.; Rong, J.D.; et al. Effects of different biochars ammendments on physiochemical properties of soil and root morphological attributes of Fokenia Hodginsii (Fujian cypress). Appl. Ecol. Environ. Res. 2019, 17, 11107-11120. [CrossRef]

75. Sprugel, G.; Ryan, M.G.; Brooks, J.R.; Vogt, K.A.; Martin, T.A. Respiration from the Organ Level to the Stand. In Resource Physiology of Conifers; Academic Press: Cambridge, MA, USA, 1995; pp. 255-299, ISBN 9780126528701. 